\title{
Botswana and Pivotal Deterrance in the Zimbabwe 2008 Political Crisis
}

\author{
Obonye Jonas $^{2}$, David Mandiyanike ${ }^{3}$ and Zibani Maundeni*,1 \\ ${ }^{1}$ Political Science at the University of Botswana, Botswana \\ ${ }^{2}$ Department of Law at the University of Botswana, Botswana
}

\begin{abstract}
This article seeks to explain the pivotal role that Botswana played in the light of the Zimbabwe political crisis after the 2008 election. It argues that Botswana was able to apply pivotal deterrence in Zimbabwe between the opposition Movement for Democratic Change (MDC) that claimed to have won the March 2008 presidential election and the Zimbabwe African National Union (ZANU PF) that claimed to have won the June 2008 presidential re-run election in which Robert Mugabe stood alone. This article deploys the theory of 'pivotal deterrence' to investigate the influence that Botswana had over the MDC and ZANU PF.
\end{abstract}

Keywords: Botswana, pivotal deterrence, preventing civil war, Zimbabwe, Southern Africa.

\section{INTRODUCTION}

This article is about preventing civil wars. While the theory of pivotal deterrence has been used to explain how deterrer states can prevent war between two other states, it is used differently in this article to explain how civil wars can be prevented. The article seeks to explain the role of a pivotal state in conflicts between political parties in another country who have the potential to spark a civil war. The Zimbabwean crisis is our case study. Our argument is that Botswana played the role of a pivot and prevented the break off of civil war in Zimbabwe between Zimbabwe African National Union (ZANU) militants and those of the Movement for Democratic Change (MDC). What this suggests in a broad sense is that civil wars break off if other states fail to play the role of pivot.

This article has several sections. It starts by outlining the theory of pivotal deterrence. Section two summarizes the Zimbabwean political crisis and the risk of civil war. Section three describes the resources possessed by Botswana as the pivot state. Section four looks at Botswana's revolving relationship with MDC and ZANU PF. Section five looks at whether the role of South Africa aided or complicated Botswana's pivotal role. Section six provides a conclusion. We believe that this theory helps to capture the significant role that Botswana played in preventing a civil war breaking out in Zimbabwe.

Pivotal deterrence theory was developed by Timothy W. Crawford (2003) who explains that 'Pivotal deterrence involves the manipulation of threats and promises in order to prevent war. Like other forms of deterrence it tries to prevent war by making potential belligerents fear the costs, by confronting them with risks they do not want to run' (2003: p.5). Crawford (2003: 5) also explains that '...the deterrer (in this

*Address correspondence to this author at the Department of Political Science at the University of Botswana, Botswana; Tel:+267 3552740/

+267 72718331; Fax: +267 3185099; E-mail: maundeni@mopipi.ub.bw case Botswana) must hold a pivotal position between the adversaries, which means that it can easily align with either side than they can align with each other and that it can significantly influence who will win in a war between them'. In addition, Crawford explains that 'a pivotal deterrer will try to maintain flexibility and avoid firm commitments to either side. The point here is not merely that the pivot strives to maintain and use flexibility that others - because of the conflict between them - do not have. Thus, by playing both sides against the middle, leaving them uncertain and afraid of what it may do if they go to war, a pivot may use its flexibility to deter them from fighting and to encourage them to compromise' (p. 7). Furthermore, Crawford says that both sides would be deterred if (and only if) they believed the pivot would align against them (Crawford 2003: p.7). Both sides must also believe that the pivot would not stand aside if they go to war (ibid, p.7). The assumptions Crawford makes is that 'each adversary would rather the pivot were aligned with it than anything else, and would rather the pivot were neutral than aligned against it' (Crawford 2003:p. 6). The theory works in scenarios in which the pivot believes that both sides harbour aggressive aims towards the other, and that under some more or less favourable conditions they would use force to achieve them (Crawford 2003: p.6). In situations in which one side is decidedly stronger (ZANU PF in this case); 'the pivot must instil contradictory fears in the adversaries. To the one who would not choose war without the pivot's support (MDC), the pivot will hold out the threat of neutrality. To the one who would go to war if the pivot were neutral (ZANU PF), it will hold out the threat of an alliance with its enemy. We want to apply this theory to explain the role Botswana played to help avert a civil war in Zimbabwe during and after the 2008 elections.

\section{POTENTIAL FOR CIVIL WAR IN ZIMBABWE}

The question is whether there was any potential for civil war during the Zimbabwe political crisis. The Southern African region has a blood-spattered history of liberation wars 
against colonial subjugation and white minority rule, ${ }^{1}$ as well as lengthy and protracted civil wars that ensued after independence - which wars were mainly a contestation between local belligerents for control of the levers of state power. Examples of these latter civil wars include the Angolan civil war (1975-2002), Mozambican Civil War (1975-1992) and the Namibian civil war (Caprivi Uprising of 1999). Since the end of Angolan civil war in 2002, Southern Africa has not experienced any civil war. Compared to other regions of Africa, the southern African region has enjoyed relative political stability with lesser civil strife. It has made admirable strides in areas of governance, human rights and the rule of law. Successive international indices such as the Mo Ibrahim Index have always ranked Southern Africa ahead of all other regions of Africa in the area of governance. According to the 2011 Mo Ibrahim index, Southern Africa scored the highest regional average of $58 \%$ in governance. According to Mandiyanike (2010) and Sachikonye (2011) the 2008 general elections were the most violent in the annals of Zimbabwe's post- independence history and the nadir of the Zimbabwe crisis. They observe that this political crisis had mutated into a number of other related crises - food security, fuel crisis and collapse in the rule of law.

The enduring amity of Southern Africa was nearly disrupted in 2008, when Zimbabwe nearly slid in a civil war following the disputed elections which returned Robert Mugabe to power after his arch-rival Morgan Tsvangirai withdrew from the presidential race citing escalating statesponsored violence directed against his supporters (Perry, A. 2008). The Human Sciences Research Council (2008) adds that these elections 'were like no other African country has witnessed in over five decades. They were a total war that left the country badly divided. They left Zimbabwe teetering on the brink of civil war. The stakes were high. The international community had hoped that the elections would serve as a conflict aversion strategy to break Zimbabwe's eightyear political strife accompanied by heart rendering economic malaise' (Human Sciences Research Council 2008). Unfortunately the aftermath of the elections saw Zimbabwe sliding into an even deeper political crisis than before the elections. According to one Non-Government Organisation, Women of Zimbabwe Arise-WOZA, the run-off election was "a total war rather than a democratic contest" (WOZA). ZANU-PF militias, state security units and the war veterans ran rampage and wreaked havoc, unleashing terror to perceived enemies - those that did not support Mugabe. According to Bearak, prior to the elections, President Mugabe himself openly declared that his supporters were armed and ready to go to war rather than conceding defeat to the opposition, which in his view would usher in a political order presided over by quislings of western powers (Bearak 2008). Speaking at the burial of his former military aide in 2008, President Mugabe was quoted by Reuters News Agency as rhetorically asking, "these pathetic puppets taking over our country?" and saying "Let's see. That's not going to happen" (ibid). Bevan notes that still at the occasion of the burial of his former military aide, Mr Mugabe is reported to have threateningly stated that " $[\mathrm{w}] \mathrm{e}$ are prepared to fight for our

\footnotetext{
${ }^{1}$ Zimbabwe fought a gallant liberation war against colonialism and apartheid in the 1970s.
}

country or to go to war if we lose it - as happened to our forefathers" (Bevan 2008). He also notes that Mugabe reported to have variously called his opponents as "thugs", "stooges", "traitors" and as "puppets", who will never rule Zimbabwe as long as he and those with whom he fought the liberation war are still alive (ibid). Perhaps there was no greater sign of a country at cross roads than this declaration.

According to Mangena (2011), after the disputed harmonised elections in March 2008, ZANU-PF began arming to the teeth, seemingly in preparation for war. It began attempts of importing military hardware from China. For instance, in April 2008 a freight liner from China was tracked by British Intelligence, M16, to the South African Port in Durban where it was refused permission to dock after protests from trade unions and diplomatic pressure from both Britain and the USA. On board the cargo liner were "1000 rocketpropelled grenades, 2000 mortar rounds, and three million rounds of ammunition. MI6 agents in South Africa believed the arsenal was intended to further cow Zimbabwe's starving population” (Mangena 2011). The weapons cargo was destined for Zimbabwe and given the tensions at the time could reasonably be suspected to have been intended for use in in a possible civil war.

From the ZANU PF side, it appeared a warlike bug had hit the party. ZANU PF Presidential candidate Robert Mugabe was reported to "have come up with this 'warlike' strategy after meeting his JOC advisors before the April Politburo meeting. The import of this was to reduce the run-off contest to a battle between the bullet and the ballot”. Phrases from the second Chimurenga were rekindled as talk of freedom having been won by the bullet and to be protected by the bullet became rampant. Mugabe himself was to borrow from the speeches of the liberation struggle whereupon he had declared that "...our votes must go together with our guns; after all any vote ... shall have been the product of the gun. The gun, which provides the votes, should remain its security officer, its guarantor" (Mugabe, 1981).

The rhetoric from history was not unsubstantiated. A newspaper in Zimbabwe, for example, reported that "[Mugabe] said the party must establish an almost military/warlike leadership which will deliver. The president and first secretary said the party must mobilize massively to achieve a resounding victory in the run-off. He said party members must understand this was a sink-or-swim election" (Zimbabwe Independent 2008). The military responded by taking over campaigns for the run-off election and thus began a campaign of threats of civil war.

One analyst, Masunungure (2009), argues that "available evidence suggests that the governing regime came to the conclusion that the party had failed in the 29 March 2008 elections and therefore that the military should lead the march to the 27 June 2008 presidential run-off”. This position was to be buttressed by Mugabe who described the conduct of his political party during the election as "slumber in circumstances of an all-out-war" (ibid). That the military was heavily involved in strategies for the campaign and their execution and the head of the party continuously spoke of war suggests ZANU PF viewed this election as one that was not to be won by the ballot. 
The war threats were taken over by Zimbabwe military generals who addressed voters. Of note is a speech that Major-General Engelbert Rugeje gave in Masvingo where he told the electorate that 'this country came through the bullet, not the pencil. Therefore, it will not go by your ' $\mathrm{X}$ ' of the pencil' and that upon his return 'the helicopter will be full of bullets" (Financial Gazette 2008). To demonstrate that such threats were not empty promises, "in the northern part of the country in Mashonaland West, soldiers reportedly handed out bullets to villagers and told them: 'If you vote for MDC in the presidential run-off election, you have seen the bullets; we have enough for each one of you, so beware' (Masunungure op cit).

According to Masunungure, political figureheads were also issuing their fair share of threats. An MDC victory at the polls was painted as a declaration of war. In an address with school heads also in Masvingo, then Finance Minister Samuel Mumbengegwi was reported to have equated an MDC victory with a declaration of war. Addressing school heads in Masvingo province, he admonished: 'This is up to you, if you want peace, you vote for us. If you vote for the MDC, we will go to war' (Masunungure op cit).

Following the failed electoral process in Zimbabwe, several leading research organisations, such as Open Society Initiative for Southern Africa (OSISA), based in Johannesburg, Human Sciences Research Council (HSRC), based in Johannesburg, and the Africa Policy Institute (API), based in Nairobi and Pretoria fretted that Zimbabwe was on the brink of a civil war and that never in its history was she ever so close to it. Kwandiwe Kondlo the chief of the Council's democracy research programme, was reported as saying, 'the miscarried electoral exercise was a recipe for civil war because there is no yielding ground' and that '[a] low-intensity war has begun and the situation is getting out of control' (Joint HSRC/API Report 2008). Whilst indicating that initially violence and savagery were not part of the MDC strategy or policy to dislodge ZANU-PF from power, he pointed out that the MDC had established local "democratic resistance committees" to counter the terror and violence that was being unleashed by Mugabe's ZANU-PF party against them in their efforts to take the war to the "state-sponsored goon militias” (Nkomo 2008). In Kondlo's view, MDC's actions of greater organisation were setting the stage for an all-out war. He asserted that "Hell is being let loose," and that "[w]e do know almost certainly that some of them [MDC supporters] have begun military-style training" (Scotsman 2008). Kondlo added that "[t]he culture of violence that comes from ZANU-PF is gradually becoming part of the culture in the MDC" (ibid). Commentators have observed that the, 'MDC youth and general public are increasingly fighting back, and it is likely that their responses will become increasingly sophisticated' (Joint HSRC/API Report op cit p.17). Few days before the run-off, the HSRC/RPI Report observed that 'the mood of frustration is beginning to be felt at the top echelons of the MDC' (ibid). The party was surviving under huge pressure from supporters, particularly the youth to fight fire with fire to ward off ZANU-PF's violence against it (Chitiyo 2008). According to the HSRC/API report (op cit p.35), state-sponsored violence against MDC supporters had generated a "parallel emergence of retaliatory violence by the opposition which, though still covert, appears to be gradually acquiring a more structured and programmatic character". The report further argued that President Mugabe was to use violence to assume absolute monopoly of state apparatuses after his disputed electoral victory, which will rapidly accelerate economic failure and will ultimately lead to "unrest and civil war" in no time (ibid). The report further urged SADC and the international community to work closely to establish a "neutral and professional disciplined force" and to pull out "war veterans and youth militias from the streets and villages" to help Zimbabwe stir away from the direction of civil war (ibid). To avert wider anarchy or a civil war, the authors recommended that regional leaders move swiftly to "broker a sustainable executive power-sharing arrangement, leading to a government of national unity with clear timeframes" (ibid p.34). In a statement to the media in 2008, OSISA made a clarion call to SADC to move speedily to halt "increasing militarisation in Zimbabwe" (OSISA 2008). The Initiative warned that the country was at risk of sliding into wider conflict of damaging proportions. According to Chinaka (2008), so clear were the signs of an impending civil war to the extent that South Africa announced that it was doing everything in its power to avert the outbreak of civil war in Zimbabwe. Makochekanwa and Kwaramba (2010) stated at the time that Zimbabwe was 'suffering from war-like trauma to its polity ...' and was '....significantly susceptible to crisis.' But it is the pivotal deterrence role played by Botswana that is the focus of this article.

\section{THE EXTENT TO WHICH BOTSWANA WAS A PIVOT}

Our argument is that Botswana occupied the position of a deterrer between both parties. Its involvement as a deterrer is assumed to have influenced both MDC and ZANU PF to avert civil war and to cooperate in forming a government of national unity. First, we will demonstrate that Botswana was close enough to the MDC to have believed that Botswana would intervene militarily on its side if civil war broke off.

To begin with, when electoral violence erupted in Zimbabwe in 2008, Tsvangirai fled into Botswana where he was accommodated in a secret location in Gaborone, Botswana's capital. Botswana's Sunday Standard newspaper (Pitse 2008) quotes Tsvangirai 'thanking Botswana for hosting him, something he said comes at a great cost to the country'. In addition, the newspaper quoted Tsvangirai 'describing as unfortunate allegations from the Zimbabwean authorities that the MDC was training militias in Botswana in preparation for a regime change'. Mmegi newspaper also quoted Tsvangirai denying the involvement of his party in the shooting and wounding of Zimbabwe's Air Force commander, Air Marshall Perence Shiri'. Botswana was also quoted in Mmegi newspaper, denying allegations that 'Botswana has availed its territory, material and logistical support to $\mathrm{Mr}$ Morgan Tsvangirai's faction for the eventual destabilization of Zimbabwe to effect illegal regime change'. Mmegi quotes Botswana's Foreign Affairs Minister saying 'the Government of Botswana totally rejects these unsubstantiated allegations, which are obviously nothing more than an excuse to engage in acts of intimidation and harassment of innocent Zimbabweans and a desperate attempt to divert attention from the real issues facing Zimbabwe today'. 
After denying the allegations by the Zimbabwean authorities, Botswana's Minister of Foreign Affairs is quoted in Sunday Standard (Pitse 2008), reporting in the Botswana Parliament that:

As an immediate neighbour to Zimbabwe, sharing more than $600 \mathrm{kms}$ of common border, with the high level of people to people contact between the two countries, Botswana naturally takes keen interest in developments in Zimbabwe. As a party that is directly affected it is our interest to see an amicable and peaceful resolution to the political crisis in that country'.

The minister further added that it is regrettable that ZANU-PF continues to act as if they are the senior partner in the negotiations wielding the power of veto on the implementation of the Agreement. This does not reflect a genuine and credible commitment to equitable power-sharing. The full and effective implementation of the Global Political Agreement signed in Harare, Zimbabwe on 15 September 2008 is crucial to ending the crisis of legitimacy in that country. In this respect, the Government of Botswana wishes to reiterate its strongly held view that if the Agreement cannot be implemented as soon as possible, the international community should demand a re-run of the presidential election in Zimbabwe under international supervision so that the long suffering people of Zimbabwe can resolve the impasse by voting to decide who their true leaders should be.

Secondly, a South African newspaper, City Press, reported that MDC President Tsvangirai 'was travelling to and from South Africa using an aircraft supplied by President Ian Khama'. However Botswana denied this report. Third, President Ian Khama refused to recognise Mugabe as the legitimate president of Zimbabwe after the violent presidential run-off. However, when Tsvangirai signed the Global Political Agreement against Botswana's and Tanzania's advice that he should delay and negotiate for more concessions, Botswana adopted a different position to the effect that 'Tsvangirai prepared his bed now he must sleep on it'. So that even if Botswana supported Tsvangirai during the difficult times, it still maintained its flexibility and was ready to abandon him if the need arose.

In contrast, we will also demonstrate that Botswana was close enough to ZANU PF to have believed that Botswana would intervene on its side. For instance, people who had gathered to witness the signing gave a thunderous applause as President Khama entered, to which President Mugabe also chanted 'Botswana, Botswana, Botswana, ooh'. President Mugabe went on to assume a friendly posture by reminding the young Botswana president of his relationship with his late father, Sir Seretse Khama. Muronda quotes Mugabe saying

"We made very good friends ... but unfortunately he passed away... but we have established very strong ties, and I would want these strong ties to continue” (Muronda 2008)." To his chagrin, President Mugabe remarked he would never attack in public a fellow African country or leader and political analysts have indicated he, (Mugabe) in essence had implied 'he would not do what President Khama had done” (ibid).
Thus, President Mugabe himself acknowledged the friendly relations that always existed between Botswana and Zimbabwe.

In a discussion with a former Botswana Defence Force (BDF) officer during the course of this write up, it became clear that Botswana has collaborated with the Zimbabwean army even during the Zimbabwe crisis. This has been evidenced by exchange visits between the BDF and Zimbabwe National Army and some officers have been to the Zimbabwe Military Academy in Gweru. At the BDF Staff College (then in Block 8), some tapestry from the Zimbabwe Military Academy were proudly displayed in the foyer. The relations between military officers are equally cordial. During our discussion, the army officer indicated that even at the height of the Zimbabwe crisis, the Batswana counterparts used to buy groceries for their Zimbabwe counterparts. This was also done for confidence building. Botswana's former army commander Lieutenant General Tebogo Masire allayed the suspicions and frosty relations during a tour to Zimbabwe when he described as malicious and false claims that the two countries were at loggerheads. "We have good cordial relations despite what the media say. We meet very regularly in forums between our two defence forces and discuss strategies on how to combat illegal border crossing, poaching and cattle rustling' (Mmegi 2012) The implied military cooperation gives the impression of a Botswana that was always ready to stand with the ZANU PF government.

However, as the Zimbabwe crisis was escalating following the disputed elections, there is no doubt that relations between Botswana and Zimbabwe went frosty. Botswana entered the war talk, and was decidedly on the MDC side. Botswana began efforts of posturing - a move that was interpreted by pundits as preparatory work to attack Zimbabwe. It is reported that the government of Botswana took a decision to deploy a BDF contingent along the BotswanaZimbabwe border, armed with heavy artillery (Wordpress 2008). Probed by a local newspaper, Sunday Standard, on the truthfulness of this development, Justice and Security Minister, Brigadier Dikgakgamatso Seretse is reported to have curtly responded: "This is a very sensitive matter; therefore, I can neither confirm nor deny any deployment of soldiers along the Zimbabwe-Botswana boarder" (Wordpress, ibid). One would expect that if there was no truth in the allegation, the Minister would have simply dismissed the issue as a mere twaddle without any prevarications. And for bilateral relations sake, Botswana would have assured Zimbabwe that all is well between the two countries. Our argument is that the Minister's equivocations point to the direction that indeed plans were underfoot in Botswana to participate militarily if civil war broke out in Zimbabwe. When the Zimbabwean crisis was still at its height, Bloomberg News also alleged that Botswana's President Lieutenant General Ian Khama had said Botswana would intervene militarily in Zimbabwe if President Mugabe does not step down (Willie 2008). According to well-placed sources such as Wikileaks cables in anticipation for war against Zimbabwe, Botswana approached the United States for arms of war and related military assistance (Newzimbabwe.com 2012).

According to Wikileaks cables Major General Gobuamang Tlhokwane of the BDF is said to have approached a 
defence cooperation official at the US Embassy in Botswana on 14 July 2008, and requested for military assistance (ibid). It is reported that:

"He asked the US to help with global positioning systems, anti-tank missiles, short range air defence systems, F5 under-wing tank system and helicopter gunships to help Botswana prepare for the war" (ibid).

According to the cable, in justifying the request, Major General Tlhokwane is said to have stated that:

"The requests for anti-tank missiles and a short range air defence system make sense in the context of the current situation as Zimbabwe has more numerous and more advanced tanks and aircraft in their inventory than Botswana" (ibid).

This shows that while Botswana had always been friendly to ZANU PF, it was ready to switch sides in defence of democracy and on the side of the MDC. The fact that it was seeking material support from the US suggests that it was readying itself for a military confrontation against the ZANU PF government in Zimbabwe. However, it is said that the US through its mission in Botswana, turned Botswana down on its request, advising that provision of military assets could "harm America's interests in the region and possibly trigger an arms race" (ibid). The Wikileaks reported that the US Mission argued that:

"This Mission is mindful of how a closer US government and (Botswana) security relationship, with possible provision of new arms and equipment, might impact our ongoing diplomacy in Southern Africa and beyond" (ibid)."

Adding that:

"We should examine ways to enhance institutional ties and other support for the government of Botswana and the Botswana Defence Forces where appropriate, but also in a manner that will not harm overriding U.S. interests in Africa" (ibid).

There is no doubt that such a US response weakened the credibility of Botswana's role as a pivotal deterer. However, it is not clear whether in fact Washington heeded the Missions counsel not to afford Botswana military assistance against Zimbabwe or whether weapons were secretly delivered. We have also found no evidence that suggests that Botswana actually went on a buying spree, acquiring military hardware in preparation of the impending intervention.

But Botswana's manoeuvres were having effect on the ZANU-PF led government. According to Sibanda (2008), in a veiled reference to Botswana, President Mugabe warned 'neighbours' to 'think twice' before going to war with Harare' adding that 'if there is a country, a neighbouring country that is itching for a fight, ... then let them try it, they will taste the salt of the fight'. Zimonline (2008) adds that Zimbabwe's Justice Minister, Patrick Chinamasa accused Botswana of what he called 'extreme provocation' while other officials of the Zimbabwean government accused Gaborone of training bandits or a rebel army for Prime Minister Morgan Tsvangirai to overthrow President Mugabe's regime. Muchemwa (2008) reports that to counter Botswana's move, war veterans' leader Jabulani Sibanda ordered ex-combatants to be on high alert claiming that Botswana was threatening an invasion. The overall impression as gleaned from Botswana's actions clearly point to the ineluctable conclusion that should Zimbabwe had descended into a civil war in 2008, Gaborone would have intervened.

According to Lebow (1994), international relations theories, especially realism and neo-realism postulate that generally states act in their national interest and hardly take risks when there is nothing to gain for them. He also says that liberals too have this assumption. This is to say states will not intervene in any conflict militarily unless they have something to benefit from doing so. Therefore, to prove that indeed Botswana would have intervened and that it played the role of a pivot in the likely civil war in Zimbabwe, we must show that it was in Botswana's national interest to do so. In this regard, it is important to note that the concomitant feature of every civil war is an exodus of refugees fleeing their own countries and seeking sanctuary in neighbouring countries. No doubt Botswana, a country that shares the longest border line with Zimbabwe would have become the destination of choice for most refugee seekers from Zimbabwe. The problem of refugee influx into Botswana would have created great problems for Botswana in its wake. According to the World Development Report of 2011:

Developing countries that host refugees for protracted periods experience long-term economic, social, political, and environmental impacts. From the moment of arrival, refugees may compete with local citizens for scarce resources such as water, food, housing, and medical services. Their presence increases the demands for education, health services, infrastructure such as water supply, sanitation, and transportation, and also in some cases, for natural resources such as grazing and firewood.

On the economic front, experience shows that refugee influxes can have damaging macro-economic impacts on the economy of the host country. According to the World Development Report [ibid], some of these impacts emanate from increasing 'but uncompensated public expenditures related to the care and maintenance of the refugee population'. A study by Salehyan and Gleditsch (2006) dealing with impacts of refugees on national economy in Malawi in the 1990s concluded that 'significant direct and indirect expenditure related to refugees affected the scale of the government's capital investment in the social and infrastructure sectors'. They also concluded that refugees can also create security problems for host countries. Salehyan and Gletsch (ibid) link refugee influxes with security challenges; this more so in the case where the sending regime is hostile to the country receiving refugees. According to them, the influx of refugees from neighbouring countries can destabilize host countries in several ways: (i) by using the host country as a military zone to re-group, re-organise and attacking their own country, triggering reprisals from the latter and turning the territories of the receiving state into a battleground, (ii) snipers or spies camouflaged as refugees may enter the host country and wreak havoc especially in a situation where already there is diplomatic tension between the two countries, as was the case between Botswana and Zimbabwe in 2008. As shown above, the Harare regime accused Gaborone of harbouring MDC-T militant camps. According to Skeldon (1998), dissident migrants move to countries that are sympa- 
thetic to their cause and these countries in turn may "pursue their policy objectives through the linkages developed by the migrant community back to their homeland in attempts to change forms of government, or change policies perceived not to be in the best interest of the host country". This was observed with the Rwandese refugees in the DRC (ibid). Such observations connect refugees to national security.

Next we must show that Botswana had the capability to intervene successfully in Zimbabwe if it was minded to do so. Neo-realists such as Lebow (op cit) argue that states/actors in international relations act on the basis of their capabilities. Lebow (op cit) also argues that capabilities in an anarchic world system are distributed differently and they condition the policy choices that states have. Did Botswana have the capability to play pivot? The answer to this can only be in the context of Botswana believing that the position she adopted would be supported by global powers. Botswana clearly believed that her stand would find favour with both Britain and the USA. Approaching the USA seeking weapons of war as shown earlier indicates that Botswana had expected some sympathy from the US. Regionally, Zambia under the late President Levy Mwanawasa, had also adopted a stance against ZANU PF's aggressive tendencies. Thus Botswana was not isolated in the position she took. The likelihood of being supported by the US and the British therefore might have provided some sort of impetus for Botswana to pivot. While one can contend that there was no evidence of express support for Botswana's likely participation in Zimbabwe's civil war, equally there is no express proof that such a position would not have received their support. This gives us a firm foundation from which to proceed in deciding that in all likelihood, Botswana would have intervened in Zimbabwe.

Botswana had a lot of interest that the impasse between MDC and ZANU PF was resolved peacefully or even militarily. With thousands of Zimbabwean illegal immigrants already staying in the country and contributing to the rising levels of crime, Botswana sought to prevent a war situation that could have produced a much larger influx of refugees. Having warmed up to the MDC, it was sending signals to ZANU PF that it would not stand by if violent hostilities erupted. Botswana to be regarded as a pivot between MDC and ZANU PF, it must be shown to have leverage over both of them. It must be known to occupy a middle ground with great potentials to influence both of them. It must also be decidedly anti-war between the two parties.

Botswana has been sending strong messages to ZANU PF that any violent takeover of power will not be tolerated and was most likely to invite it into the conflict. Part of its messages included its abandonment of multilateral politics (boycotting SADC meetings if Zimbabwe was represented) and choosing unilateralism and playing to the gallery over the Zimbabwe impasse. For instance, on $4^{\text {th }}$ November 2008, Botswana's Minister of Foreign Affairs, Phandu Skelemani addressed students at the University of Botswana on Zimbabwe. On the $3^{\text {rd }}$ of November 2008, President Ian Khama had talked about Zimbabwe in his state of the nation address to the national parliament. Both of them boycotted SADC summits where Zimbabwe was represented. The Botswana Government's public criticism of ZANU PF and its boycott- ing of SADC summits could be interpreted as sending clear signals to that party to not go in the extreme of provoking a civil war.

Botswana had boycotted an earlier SADC meeting called to discuss the Zimbabwe issue. Minister Skelemani explained the boycott in these terms: 'our decision was simply based on the fact that the legal process of producing a Government in Zimbabwe had failed and as a result those who claim to represent a government in Zimbabwe at the political level should be excluded from attending SADC and African Union meetings as their participation in these meetings would be equal to giving them unqualified legitimacy'. Botswana's position in both SADC and AU was a minority one, but it was a significant one as it sounded a warning to ZANU PF. While both organizations welcomed Robert Mugabe into their midst, Botswana stood out to Mugabe and openly declared its hostility to his violent conduct.

Botswana was not even deterred that other SADC members chose to go soft on Mugabe and his ZANU PF party. As minister Skelemani explains in the Sunday Standard newspaper of $4^{\text {th }}$ November 2008, 'other SADC member states, for reasons best known to them, held a different view' (Pitse 2008, p5). The ZANU PF government correctly read the position and started claiming that Botswana was preparing for war and started making allegations that the country had training facilities for MDC guerrillas. A special SADC summit scheduled for the $9^{\text {th }}$ November to discuss the Zimbabwe impasse was attended by Botswana's vice president and minister of foreign affairs. President Khama knowingly left the country earlier in the week to attend an environmental meeting in the United States and missed the SADC summit which was attended by only five head of states. Thus, while SADC structures pursued a multilateral approach and complicated its pivotal position, Botswana pursued a unilateral approach of boycotts and distinguished herself as the pivot by threatening military intervention.

By boycotting meetings, Botswana's position in SADC became more pronounced and anti-ZANU PF. First, the boycott meant that the SADC and Mugabe could deliberate for hours and Botswana was not going to take them seriously unless there was power-sharing. Botswana actually started criticizing SADC for the manner it was handling the Zimbabwe issue, particularly the welcoming of Mugabe in its summit meetings.

Even after the power-sharing agreement was brokered, President Ian Khama continued to express misgivings about such arrangement. Burgis (2009) argued that Mr Khama's criticism of President Robert Mugabe, was a rare exception to many African leaders' willingness to tolerate autocrats in their midst. This was a crucial prop to Morgan Tsvangirai. Following the 2009 car crash in which Mr Tsvangirai's wife Susan was killed, Mr Khama airlifted in his own jet Zimbabwe's injured prime minister for treatment to Gaborone, Botswana's capital. According to Burgis (2009), speaking before the accident, Mr Khama had expressed deep misgivings about Mr Tsvangirai's decision to serve as Mr Mugabe's prime minister. He said he doubted Mr Mugabe's good faith in the agreement and whether they would be able to work together to rebuild the country's shattered economy. 


\section{DID SOUTH AFRICA COMPLICATE BOTSWANA'S PIVOTAL DETERRENCE?}

First, when the Zimbabwean saga was playing itself out, the then South African president Thabo Mbeki gave the impression that his government was very close to that of Zimbabwe's Mugabe government. President Mbeki was notorious for defending President Mugabe even in the face of indefensible evidence. It is widely believed that the camaraderie between Presidents Mbeki and Mugabe stemmed from their common legacies of the struggle against white setter rule in their respective countries and the resultant anti-colonial collegiality between them. When Zimbabwe won its independence in 1980, after the defeat of the white minority rulers, South Africa still had slightly over a decade to win its own struggle against apartheid. According to Jonasi (2010), during that time, Zimbabwe supported and even provided sanctuary to South African nationalists. Addelmann (2004) adds that the white settler legacy still impacts negatively on both countries' bodies politic and economies today. In the light of the above, it could be observed that it was near impossible for former President Mbeki to criticise President Mugabe's excesses and abuses. According to Bearak (2008), at the height of the election dispute in Zimbabwe, on 12 April 2008, after visiting President Mugabe in Harare, on his way to the SADC summit, President Mbeki told the world that Zimbabwe was not in any crisis, and explained that the delay in releasing the presidential results, which were withheld for two weeks, was only a 'natural process' and that Zimbabweans and the international community must exercise patience while awaiting their release. ${ }^{2}$ So, at least from a diplomatic point of view, South Africa under Thabo Mbeki had taken sides with Mugabe's regime in the election dispute. There is no doubt that this was compromising Botswana's pivotal deterrence role.

In addition, what could also have frustrated Botswana's diplomatic and military manoeuvres was the fact that South Africa was just ambivalent in approach - not showing whether or not it would have intervened militarily at all in the war should it have erupted. In this regard, Botswana's pivotal deterrence role was compromised and enhanced at the same time. Compromising Botswana's pivotal role was the fact that South Africa was economically and militarily strong and this could have significantly influenced Botswana to be cautious. According to Rothberg (1995), at the time of the Zimbabwe political crisis, South Africa produced, for instance, approximately $80 \%$ of the Southern Africa Development Community's (SADC) GDP; the regional trade imbalance was at about 7:1 in South Africa's favour, and it also dominated foreign direct investments (FDI). There is no denying South Africa's domination of the region. Its gross domestic product (GDP) of US\$118 billion is four times larger than the combined GDPs of the other ten nations of southern Africa, including the Democratic Republic of Congo and Tanzania. South Africa's economic preponderance meant that its military clout was enormous. Its combined army, air force, and navy of 100,000 is far larger, better organized, and trained than that of Zimbabwe or those of the smaller,

\footnotetext{
${ }^{2}$ The election results were withheld for more than two weeks amid speculation on the part of the opposition, civil society and international community that the government was rigging them.
}

weaker nations in the region. But we have shown that Botswana either ignored the presence of South Africa or it was assured that South Africa would not oppose it militarily.

In addition, there were also signs that South Africa would not have intervened militarily. First, South Africa was then championing the role of a potential peacemaker and peacekeeper. According to Gumede (2005, p.189), South Africa was calling for a negotiated settlement. Second, during the Zimbabwe crisis, the Zimbabwe government owed South Africa's bulk electricity supplier Eskom millions of Rands in arrears, and Mbeki agreed not to suspend the service and explored the possibility of raising capital for Zimbabwe in the financial markets. It therefore seemed that Mbeki was unwilling to do anything that would further disrupt the Zimbabwe economy, thus making it almost impossible to revive and for it to pay back the electricity bill. Indeed, Landsberg and Kondlo (2007, p.8) made observations to the effect that South Africa used its political role in the continent to advance its business interests. Prys (2009) argued that the ANC was suspicious towards labour movements such as the Movement for Democratic Change (MDC), being faced with fractional struggles within the ANC itself as well as within the coalition government of South Africa. Prys continued to argue that South Africa was busy 'securing the economic ... interests of an emergent black South African bourgeoisie', which benefits hugely from rescue packages extended to Zimbabwean counterparts. Thus, South Africa was not ready for active military involvement in Zimbabwe.

In addition, having assumed the role of mediator, South Africa was considerably constrained from intervening militarily on the side of Mugabe. This was partly because a break out of the war would have been blamed on South Africa for having been a poor mediator. During his frequent visits to Harare during the Zimbabwe crisis, Thabo Mbeki was overtly partisan, a situation that would have pointed to South Africa as having contributed to any failed negotiations. Mbeki pointedly refused to meet Tsvangirai, other MDC leaders or civil society groups. Gumede (2005) argues that this in itself was strange, since no matter how much he might have disliked the party or its leaders, there was no escaping the fact that it had commanded $45 \%$ of the popular vote, even in elections that were (almost) rigged. Habib (2008, p.7) contends that the MDC routinely questioned Mbeki's neutrality as the SADC official mediator and even tried to get him replaced to no avail. Mbeki's visits to Zimbabwe became fodder for that country's state-controlled media as Mbeki and Mugabe warmly embraced each other and indeed exhibited a 'close' relationship. According to Gumede (op cit), Mbeki never publicly condemned Mugabe, as DlaminiZuma posited 'this is not going to happen as long as this government is in power'. Musavengana (2011, p.37) noted 'the unwitting complicit' of South Africa under former President Thabo Mbeki and subsequently under Jacob Zuma in the unlawful involvement of the security establishment in Zimbabwe politics. This was evident in their refusal to publish the report by the six South African retired generals who probed the orgy of violence that rocked the 2008 elections and another earlier report by Judges Dikgang Moseneke Sisi Khampepe who also discussed the political violence. 
According to Spielman (2009), Jimmy Carter was curtly dismissive of Mbeki's stance and described him as too timid and a useless mediator to the Zimbabwe political crisis. "I think he (Mbeki) has always been in bed with Mugabe pretty much, and pretty timid about contradicting his old friend, who was one of the first revolutionary freedom fighters who was successful in southern Africa,". According to Gumede (2005: p185) Mugabe took advantage of his liberation credentials and has a penchant for elder statesman status and is well known for craving affirmation and demanding respect. Gumede (ibid) further advances the notion that Mugabe regarded Thabo Mbeki as a young upstart.

\section{CONCLUSION}

This article used the theory of pivotal deterrence to analyse the role of a third party state (the deterrer) of preventing a civil situation in another country, from exploding into a full blown civil war. The theory posited that the deterrer state must be friendly to the belligerent parties, but with enough flexibility to switch sides in its support of the belligerent parties to a civil war situation; it must possess enough resources to make its military intervention a deciding factor as to who wins the war if it breaks out; its military manoeuvres must leave no doubt that it would intervene if war broke out. What this theory suggests is that civil wars (as in Syria) break out because there was no credible pivotal deterrence. In short, civil wars are preventable through the clear manoeuvrings of a pivotal state.

This article sought to demonstrate this point by considering the role that Botswana played as a pivotal state during the Zimbabwe political crisis in 2008. We have shown that Zimbabwe was evidently sliding into civil war, with both sides (the ZANU PF government and the main opposition Movement for Democratic Change) speedily becoming militant and actively arming. Our argument was that Botswana played a crucial role in preventing the civil war. It did this by being friendly to the ZANU PF government that was busy arming for war and terrorizing the opposition, and by amassing soldiers and heavy artillery on the Botswana/Zimbabwe borders, a clear signal that it intended to intervene militarily. It was clear that Botswana intended to intervene militarily against the ZANU PF government. Such a visible military posture made it uncertain that ZANU would emerge victorious in any armed confrontation, compelling it to negotiate with its rival.

\section{CONFLICT OF INTEREST}

The authors confirm that this article content has no conflicts of interest.

\section{ACKNOWLEDGEMENT}

None declared.

\section{REFERENCES}

Addelmann, M. (2004). Quiet diplomacy: the reasons behind Mbeki's Zimbabwe policy, Africa Spectrum 39, 249-276.

Bearak, B. (2008). Mugabe says he will go to war if he loses runoff vote, New York Times (2008): Available from: http://articles.sunsentinel.com/2008-06-15/news/0806140115_1_morgan-tsvangiraiopposition-party-opposition-leader [Accessed 25 May 2012].
Bearak, B. (2008). Zimbabwe Opponent Criticizes Mbeki, New York Times, February 14, 2008.

Bevan, S. (2008). Robert Mugabe threatens war on opponents as wife Grace joins battle over election. The Telegraph: Available from: http://www.telegraph.co.uk/news/worldnews/africaandindianocean/ zimbabwe/2129744/Robert-Mugabe-threatens-war-on-opponentsas-wife-Grace-joins-battle-over-election.html

Burgis, T. (2009). Harare power-sharing comes under fire, Financial Times, 8 March 2009: Available from: http://www.ft.com/cms/s/0/c4eb75d8-0c01-11de-b87d-0000779fd2ac.html\#axzz23SVJKko0 [Accessed 8 August 2012].

Chikuhwa, J. (2004). A Crisis of Governance: Zimbabwe. New York, Algora Publishing.

Chinaka, C. (2008). War vets are ready for battle, says Mugabe, Reuters, 13 June 2008.

Chitiyo, K. (2008). Zimbabwe: Presidential Rivals Fight on, The Africa Report, No11. June-July, p.36.

Crawford, T.W (2003). Pivotal Deterrence: Third Party Statecraft and the Pursuit of Peace. Ithaca: Cornell University Press.

Financial Gazette (2008), Politicians threaten to wage post-election war, The Financial Gazette, 19 June 2008.

Gumede, W.M. (2005). Thabo Mbeki and the Battle for the Soul of the ANC, Cape Town, Zebra Press.

Habib, A. (2008). South Africa's Foreign Policy: Hegemonic Aspirations, Neoliberal Orientations and Global Transformation; University of Johannesburg; Paper prepared for the first Regional Powers Network (RPN) conference at the German Institute of Global and Area Studies (GIGA) in Hamburg, Germany, 15-16 September 2008.

Human Sciences Research Council (2008). Saving Zimbabwe An Agenda for Democratic Peace Human Sciences Research Council, Pretoria and Africa Policy Institute, Nairobi/Pretoria 10 July 2008 report. Available from: http://www.hsrc.ac.za/Document-2823.phtml ttp://www. scotsman.com/news/opposition_takes_up_arms_as_Zimbabwe_ slides_into_civil_war_1_1079878 [Accessed: 24 May 2012].

Ibrahim, M. (2011). The Mo Ibrahim Index, The Index is Available from: http://uscdn.creamermedia.co.za/assets/articles/attachments/35446_2011100 3_eng2011-iiag-summaryreport-sml.pdf [Accessed 24 May 2012].

Joint HSRC/API Report, "Saving Zimbabwe an Agenda for Democratic Peace” 10 July 2008, p. 4: Available from: http://www.hsrc.ac.za/ Document-2823.phtml [Accessed 23 May 2012].

Jonas, O. (2010). A critical appraisal of the mutual engagement of African states in the African Peer Review and Universal Periodic Review Mechanisms: a human rights perspective, (2010). [unpublished LLM thesis 29].

Lardner-Burke, D. (1966). Rhodesia- The story of the crisis; London: Oldbourne Books.

Landsberg, C. (2004). South Africa: A Pivotal State in Africa', Synopsis. Policy Studies Bulletin, 7(1), 1-3.

Landsberg, C. \& Kondlo, K. (2007), South Africa and the 'African Agenda' Policy: issues \& actors (20), 13; Johannesburg: Centre for Policy Studies.

Lebow, R. N (1994). The long peace, the end of the cold war, and the failure of realism International Organization, 48 (2), 249-277,

Makochekanwa, A., \& Kwaramba, M. (2010) "State Fragility and Restoring Order in Zimbabwe” Africa Peace and Conflict Journal 3, 64-79.

Mandiyanike, D. (2010). Human Rights and Governance - a blueprint for Zimbabwe. Paper prepared for the Development Foundation for Zimbabwe Conference December 2010, Victoria Falls.

Mangena, Z. (2011). "Brits thwarted Zim arms ship”, Times Live (2011), Available from: http://www.timeslive.co.za/africa/article865780. ece/Brits-thwarted-Zim-arms-ship [Accessed 28 May 2012].

Masunungure, E. (2009). A Militarized Election: the 27 June Presidential Run-Off. In: Masunungure, E. (Ed.), Defying the winds of changeZimbabwe's 2008 Elections (p. 83), Harare: Weaver Press.

Matambanadzo, P. (2012). Armed forces averted coup, says Shiri. The herald, 6 August 2012, Available from: http://www.herald.co.zw/index.php?option=com_content\&view=article\&id=49173:armedforces-averted-coup-says-shiri\&catid=37: top-stories\&Itemid=130 [Accessed 6 August 2012].

Mmegi (2012). We enjoy cordial relations with Zimbabwe - BDF chief Available from: http://www.mmegi.bw/index.php?sid=1\&aid= 397\&dir=2012/February/Wednesday8 [Accessed 11 September 2012].

Muchemwa, M. (2008). War vets ready for war against Botswana, Available from: http://www.zimeye.org/?p=824[Accessed 2 May 2012]. 
Mugabe, R. (1981). Our war of Liberation: Speeches, Articles, Interviews. (p. 100). Gweru, Mambo Press.

Muronda, M. (2008). Mugabe rides on Khama's popularity, Sunday Standard 21 September 2008 Available from: http://www.sundaystandard.info/print_article.php?NewsID=3792 [Accessed 6 Aug 2012].

Musavengana, T. (2011). Security Sector: No transition without transformation' Open Space Issue 1, OSISA, Johannesburg, pp. 28-39.

Newzimbabwe.com (2008). Botswana sought US help against Zimbabwe military attack, 2 June 2012: Available from: http://www. newzimbabwe.com/news-5987-Botswana\%20feared\%20Zim \%20military \%20attack/news.aspx [Accessed 1 May 2012].

Nkomo, F. (2008). Zimbabwe: MDC-T Democratic Resistance Committees Behind Violence, The Zimbabwean Guardian, 21 June 2008.

OSISA (2008). Statement Available at: http://www.thezimbabwemail.com/zimbabwe/3726.html [Accessed 27 May 2012].

Perry, A. (2008). Tsvangirai Pulls out of Election, Time world Available from: http://www.time.com/time/world/article/0, 8599, 1817057, 00.html [Accessed 6 May 2012].

Pitse, R. (2008). Botswana prepares for war?, Sunday Standard., 02 July 2008. Available from: http://www.sundaystandard.info/article.php? NewsID=3380\&GroupID=1 [Accessed 11 September 2012].

Prys, M. (2009). Regional Hegemon or Regional Bystander: South Africa's Zimbabwe Policy 2000-2005. Politikon, (August 2009), 36(2), pp. 193-218.

Ranger, T. (1960), Crisis in Southern Rhodesia, London, Fabian Common Wealth Bureau.

Salehyan,I., \& Gleditsch, K, (2006). Refugees and the Spread of Civil War. International Organization 60, 335-366.

Scotsman (2008). Opposition takes up arms as Zimbabwe slides into civil war. Available from: http://www.scotsman.com/news/opposition_ takes_up_arms_as_zimbabwe_slides_into_civil_war_1_1079878 10 July 2008 [Accessed 25 May 2012].

Shamuyarira, N. (1965). Crisis in Rhodesia, London: Andre Deutsch.

Sibanda, T. (2008) Mugabe's regional war talks Available from: http: //www.swradio-africa.com/news040708/mugswartalk040708.htm [Accessed 2 May 2012].

Skeldon, R. (1998). Migration Policies and National Security In: Graham D.T. and Poku N., Eds., Redefining Security: Population Movements and National Security; New York: Praeger Publishing Group, Inc. 67.

Spielmann, P.J. (2009). Carter: Dump Thabo Mbeki as Zimbabwe mediator; Accessed: http://www.etaiwannews.com Associated Press: NY, [27 $7^{\text {th }}$ Jan 2009].

Willie, O. (2008), Zimbabwe Says Botswana Provides Army Training to MDC, 15 December 2008. Available from: http://newsgroups.derkeiler.com/Archive/Soc/soc.culture.african/200812/msg00027.html [Accessed May 1 2012].

Women of Zimbabwe Arise (WOZA). Available from: http://www.kubatana.net/html/sectors/wom010.asp [Accessed May 23 2012].

Wordpress (2008). Botswana preparing to attack Zimbabwe, Available from: $\quad$ http://butdoisay.wordpress.com/2008/07/03/botswanapreparing-to-attack-zimbabwe/Botswana, Preparing to Attack Zimbabwe, 3 July 2008 [Accessed $1^{\text {st }}$ May 2012].

World Development Report (2011). The Impacts of Refugees on Neighbouring Countries: A Development Challenge?, July 29, 2010 p. 6: Available from: http:/wdr2011.worldbank.org/sites/default/files/ pdfs/WDR\%20Background\%20Paper_Refugees_0.pdf [Accessed $4^{\text {th }}$ June 2012].

Zimbabwe Independent (2008), Mugabe Orders "warlike” campaign, The Zimbabwe Independent, 23 May 2008.

Zimonline (2008). Botswana prepared for war with Zimbabwe, Available from: $\quad$ http://www.zimonline.co.za/Article.aspx?ArticleId=6804

(C) Jonas et al.; Licensee Bentham Open.

This is an open access article licensed under the terms of the Creative Commons Attribution Non-Commercial License (http://creativecommons.org/licenses/by-nc/3.0/) which permits unrestricted, non-commercial use, distribution and reproduction in any medium, provided the work is properly cited. 